\title{
DAMPING OF POWER SYSTEM OSCILLATIONS BY TUNING OF PSS AND SVC USING PARTICLE SWARM OPTIMIZATION
}

\author{
Natarajan Karuppiah, Veluchamy Malathi
}

Original scientific paper

This paper presents a heuristic algorithm PSO based simultaneous coordinated tuning of the SVC damping controller and power system stabilizer (PSS) in a two machine three bus power system. The coordinated tuning of PSS and SVC damping controller is converted to an optimization problem which is solved by particle swarm optimization (PSO) technique. The parameters like rotor angle deviation, settling time of disturbances post fault and transmission line active power are observed. The results obtained with PSO tuned SVC and PSS are compared with those of conventional PSS and Fuzzy controlled SVC and PSS. PSO tuned SVC and PSS gives better results. The effectiveness of each control method is verified using MATLAB. The results also show that the proposed coordinated controllers have increased power system oscillations damping capability.

Keywords: Fuzzy Logic Controller (FLC); Particle Swarm Optimization (PSO); Power System Stabilizer (PSS); Static Var Compensator (SVC)

Prigušivanje oscilacija energetskog sustava podešavanjem PSS i SVC uz primjenu optimizacije roja čestica

Izvorni znanstveni članak U radu se predstavlja na PSO heurističkom algoritmu utemeljeno simultano koordinirano podešavanje regulatora prigušivanja SVC i stabilizatora energetskog sustava (PSS) u energetskom sustavu s dva stroja i tri sabirnice. Koordinirano podešavanje PSS i SVC regulatora prigušenja pretvara se u problem optimizacije koji se rješava tehnikom optimizacije roja čestica (PSO). Promatraju se parametri kao što su kut otklona rotora, vrijeme smirenja smetnji i aktivna snaga dalekovoda. Rezultati dobiveni od SVC i PSS podešenima na PSO uspoređeni su s onima dobivenim od SVC i PSS uz konvencionalni PSS i FLC. SVC i PSS podešeni na PSO daju bolje rezultate. Učinkovitost svake metode kontrole provjerena je primjenom MATLAB-a. Rezultati također pokazuju da su predloženi koordinirani regulatori povećali sposobnost prigušenja oscilacija energetskog sustava.

Ključne riječi: optimizacija roja čestica (PSO); stabilizator energetskog sustava (PSS); statički var kompenzator (SVC); regulator neizrazite logike (FLC)

\section{Introduction}

Now-a-days electrical power systems are heavily loaded with increased generation and hence the system oscillations also increase. In many cases conventional PSS are used to damp the power system oscillations. Sufficient damping is not obtained due to the non linearities of power system and increased transmission line loading over long distances. To increase the damping of the power system FACTS devices along with PSS are employed [1, 2]. The use of FACTS controllers improves the transient stability of the power system to a greater extent along with regulating the power flow in the transmission line. Of all the FACTS devices SVC is a shunt connected device which allows rapid and continuous change of transmission line impedance. SVC also improves the reliability of the power system $[3 \div 5]$.

Traditionally a lag lead compensator is used for damping oscillations because of its ease of tuning online. In some cases a number of PSSs are used to damp the oscillations. But the interaction among the various PSSs used in the transmission lines may increase or decrease the damping of particular mode of rotor oscillation. Thus it leads to the dynamic instability of the power system and moreover the operating range of the generators gets affected. Also the lack of coordination between PSS and FACTS controllers affects the stability of the power system adversely $[6,7]$.

It is essential to improve the overall system performance coordination between PSS and FACTS devices. Also the operating conditions of the power system and the non linearities in the power system impose serious challenges in coordination of PSS and FACTS. Under the transient conditions, the damping controllers should respond to the wider range of operating conditions and also minimize the interactions between them. In this paper a PSO based optimization tuning algorithm is proposed to coordinate among PSS and SVC simultaneously $[8,9]$.

The coordinated tuning of SVC and PSS is converted into an optimization problem and it is tested on a two machine three bus system. The results of Fuzzy Logic Controller tuned SVC and PSS for the same test system are compared.

\section{Static Var Compensator}

According to IEEE, Static Var Compensator (SVC) is defined as "A shunt-connected static var generator or absorber whose output is adjusted to exchange capacitive or inductive current so as to maintain or control specific parameters of the electrical power system (typically bus voltage)" [10].

\subsection{Construction of SVC}

A Static Var compensator consists of capacitors and reactors connected in shunt, which can be quickly controlled by thyristor switching. In effect SVC is a variable shunt susceptance. The susceptance is varied in response to system voltage conditions by a thyristor controlled reactor in parallel with a combination of fixed and switched capacitors and reactors. Direct and rapid bus voltage control forms the principal basis of SVC for transient stability enhancement. SVC increases power transfer during low voltage conditions. If SVC is on the system, it reduces the adverse impact of the fault. The SVCs in use nowadays are of variable susceptance type [11]. 
The SVC regulates voltage at its terminals by controlling the amount of reactive power injected into or absorbed from the power system. There are two types of SVC. They are fixed capacitor thyristor controlled reactor (FC-TCR) and thyristor switched capacitor-thyristor controlled reactor (TSC-TCR). The later type is used commonly because it is more flexible than FC-TCR and it uses lower reactor rating. The basic diagram of TSC-TCR based SVC is shown in Fig. 1.

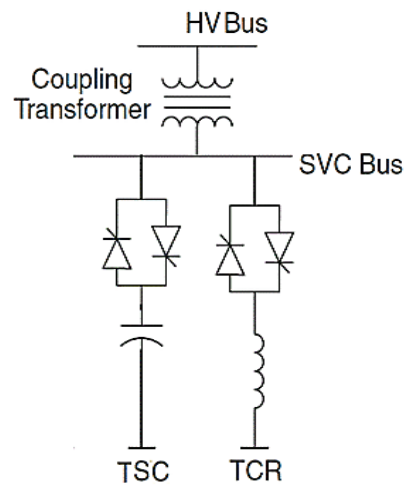

Figure 1 Basic Circuit Configuration of SVC

The SVC generates reactive power (capacitive mode) when the system voltage is low and will absorb reactive power (inductive mode) when the system voltage is high.

The variation of the reactive power can be controlled by switching capacitor banks and inductor banks which are connected on the low voltage bus. Reactors are either switched ON/OFF by Thyristor Switched Reactor (TSR) or phase controlled Thyristor Controlled Reactor (TCR).

The magnitude of the SVC is inductive admittance $B_{\mathrm{L}}(\alpha)$ is a function of the firing angle $\alpha$ and is given by

$$
B_{\mathrm{L}}(\alpha)=\frac{2 \pi-2 \alpha+\sin 2 \alpha}{\pi \cdot X_{\mathrm{s}}} \text { for } \frac{\pi}{2} \leq \alpha \leq \pi
$$

where $X_{\mathrm{s}}=\frac{V_{\mathrm{s}}^{2}}{Q_{\mathrm{L}}}$, where $V_{\mathrm{S}}=\mathrm{SVC}$ bus bar voltage and $Q_{\mathrm{L}}$ $=$ MVA rating of reactor. As the SVC uses an $\mathrm{FC}$ and a variable reactor combination (TCR-FC), the effective shunt admittance is given by,

$$
B_{\mathrm{s}}=\frac{1}{X_{\mathrm{C}}}-B_{\mathrm{L}}(\alpha)
$$

where $X_{\mathrm{C}}=$ capacitive reactance.

\subsection{Control system of SVC}

The control system of SVC is shown in Fig. 2. It consists of a measurement system, voltage regulator and synchronizing system. The measurement system measures the positive-sequence voltage to be controlled. A measurement system based on Fourier transformation is used. A voltage regulator that uses the voltage error i.e the difference between the measured voltage $V_{\mathrm{m}}$ and the reference voltage $V_{\text {ref }}$ is used to determine the SVC susceptance $B$, which is needed to keep the system voltage constant. The TSCs (and eventually TSRs) which are to be switched in and out are determined by a distribution unit that computes the firing angle $\alpha$ of TCRs. A synchronizing system consists of a phase-locked loop (PLL) and a pulse generator, sends appropriate pulses to the thyristors [11].

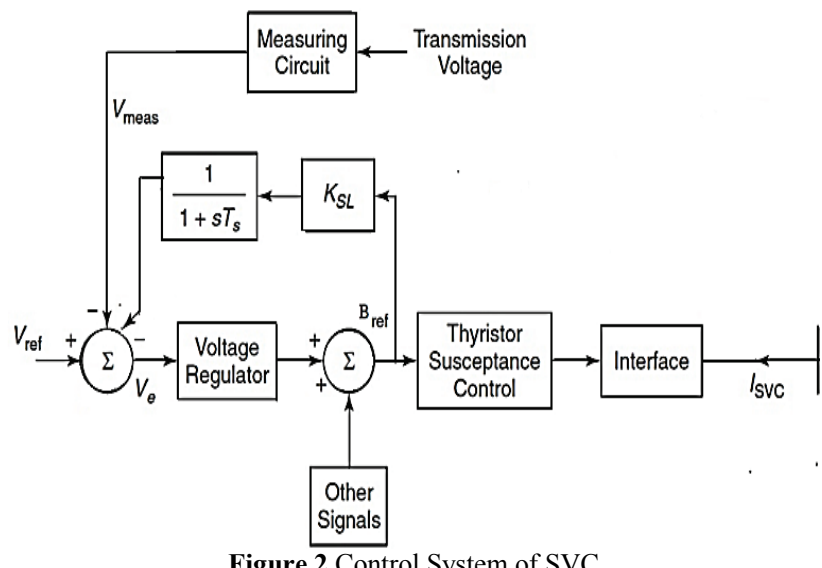

\subsection{Transient stability model of SVC}

The transient stability model of SVC shown in Fig. 3 can be obtained by assuming balanced, fundamental frequency operation with sinusoidal voltages [11]. It can be represented by the following set of equations:

$\left[\begin{array}{c}\dot{X}_{\mathrm{C}} \\ \dot{\alpha}\end{array}\right]=f_{C}\left(X_{\mathrm{C}}, \alpha, V, V_{\text {ref }}\right)$,

$0=\left[\begin{array}{c}2 \alpha-\sin 2 \alpha-\pi\left(2-\frac{X_{\mathrm{L}}}{X_{\mathrm{C}}}\right) \\ \pi X_{\mathrm{L}} \\ I-V_{\mathrm{i}} B_{\mathrm{e}} \\ I-V_{\mathrm{i}}^{2} B_{\mathrm{e}}\end{array}\right]$,

where most variables are clearly defined in Fig. 3, and the control system variables and equations are represented by $X_{\mathrm{C}}$ and $\alpha$ respectively. These equations are used to represent limits not only on the firing angle, but also on the current $I$, the control voltage $V$ and the capacitor voltage $V_{\mathrm{i}}$, as well as control variables of other types of controllers such as a reactive power Q control scheme.

\section{Power System Stabilizer Modelling}

PSS supplies an electromagnetic torque to the rotor of the generator. This torque applied is in phase with the speed variation. Through the generator excitation supplemental damping is provided through PSS. But at times due to the negative damping effect of PSS on rotor power system instabilities arise. So PSS are only effective for small disturbances.

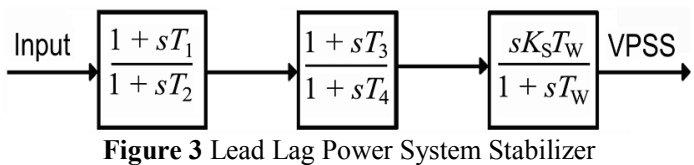


The output signal of any PSS is a voltage signal i.e., VPSS. This signal is added as an input signal to the AVR/exciter. This lag lead Power System Stabilizer consists of

1. Washout block $=s T_{\mathrm{w}} /\left(1+s T_{\mathrm{w}}\right)$

2. $\quad$ Lag-Lead block $=\left(1+s T_{1}\right) /\left(1+s T_{2}\right)$ and

$$
\left(1+s T_{3}\right) /\left(1+s T_{4}\right)
$$

3. Gain of PSS $=K_{\mathrm{s}}$

Washout Block is used to reduce the over response of the damping and it serves as a high pass filter. The phase lead block circuits are used to compensate for the lag between PSS and control action and it also helps the electromagnetic torque produced by the PSS in phase with the speed deviation of the rotor of the generators. The number of lag lead blocks depends on the power system. The PSS gain $K_{\mathrm{s}}$ is an important factor in providing the damping. The value of gain must be obtained by proper tuning of the system $[12,13]$.

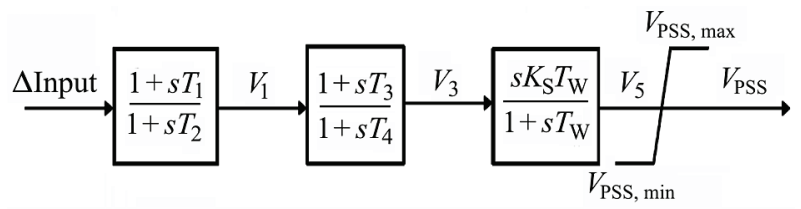

Figure 4 Lead Lag Power System Stabilizer used for damping with control inputs

The above said lead lag PSS structure is used in this paper. The control equations for this PSS are given by

$V_{\mathrm{PSS}}=\left\{\begin{array}{l}V_{\mathrm{PSS}, \max } \text { if } V_{5} \geq V_{\mathrm{PSS}, \max } \\ V_{5} \text { if } V_{\mathrm{PSS}, \max }>V_{5}>V_{\mathrm{PSS}, \min } \\ V_{\mathrm{PSS}, \min } \text { if } V_{5} \leq V_{\mathrm{PSS}, \min }\end{array}\right.$,

$V_{5}=K_{\mathrm{s}} V_{3}-V_{5} / T_{\mathrm{W}}$

$V_{3}=\left(T_{3} / T_{4}\right) V_{1}+\left(V_{1}-V_{3}\right) / T_{4}$,

$V_{1}=\left(T_{1} / T_{2}\right) \Delta$ Input $+\left(\Delta\right.$ Input $\left.-V_{1}\right) / T_{2}$,

$\left\{\begin{array}{c}\Delta \omega=\omega_{\text {mach }}-\omega_{0} \\ \quad \text { or } \\ \Delta P_{\mathrm{a}}=P_{\text {mech }}-P_{\text {elec }}\end{array}\right.$.

\section{Fuzzy Controller for SVC}

One of the most common approaches to design a controller which utilizes the qualitative information of a system and solves a problem with precision is Fuzzy Logic Controller. Here it is used in the control loop of SVC. Fig. 5 shows the basic Fuzzy Logic Controller, which consists of Input fuzzification block (binary-tofuzzy $[\mathrm{B} / \mathrm{F}]$ conversion), rule base (knowledge base), fuzzy Inferencing block and output defuzzification (fuzzy-to-binary [F/B] conversion). The voltage error and its integral value are fed as the input signals for the fuzzy controller $[14 \div 16]$.

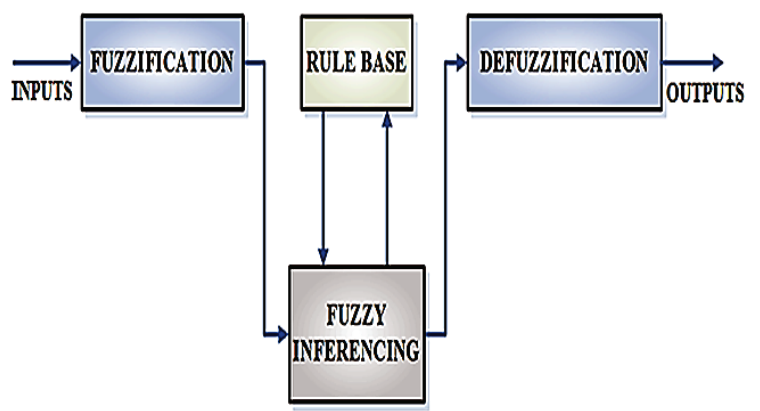

Figure 5 Basic Fuzzy controller

In this paper, seven membership functions are defined for the input and output variables. Fig. 6 shows the defined membership functions. These membership functions are used to develop a set of rules called a rule base. With two inputs and seven linguistic terms, 49 rules were developed, which is given in Table 1. In inference mechanism the rules and the input to FLC are compared to determine a proper conclusion to the current situation [17]. For inference engine Mamdani's method is used. The output of inference engine is of fuzzy value, which is to be converted into crisp value using defuzzification block. The Centroid method is employed for defuzzification process.
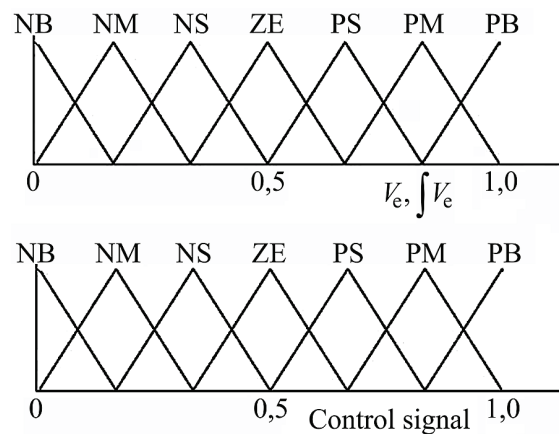

Figure 6 Membership functions for FLC

Table 1 Rules for FLC

\begin{tabular}{|c|c|c|c|c|c|c|c|}
\hline $\int V \mathrm{e} / V \mathrm{e}$ & NB & NM & NS & ZE & PS & PM & PB \\
\hline NB & NB & NB & NB & NM & NS & NS & ZE \\
\hline NM & NB & NM & NM & NM & NS & ZE & PS \\
\hline NS & NB & NM & NS & NS & ZE & PS & PM \\
\hline ZE & NB & NM & NS & ZE & PS & PM & PB \\
\hline PS & NM & NS & ZE & PS & PS & PM & PB \\
\hline PM & NS & ZE & PS & PM & PM & PM & PB \\
\hline PB & ZE & PS & PS & PM & PB & PB & PB \\
\hline
\end{tabular}

\section{Particle Swarm Optimization}

Particle swarm optimization (PSO) is a kind of optimization algorithm used to obtain the optimal solution by simulating the schooling behaviour of fishes or flocking behaviour of birds. Initially a flock of birds, in which each bird called as a particle is made to fly over the searching space. These particles will fly with certain velocity to find the best global position $\left(G_{\text {best }}\right)$ after some iteration. For each and every iteration, current position and velocity of all particles gets changed according to its current position $P_{\text {best }}$ and the current global position $G_{\text {best }}$. At maximum iteration all the particles will move towards the global solution $[18 \div 21]$. 


\subsection{Design of PSO Based Controller}

Steps of PSO as implemented for optimization of controller are as follows:

Step 1: Inputs consist of the parameters such as off time constant and Gain in the AGC of power system model.

Step 2: Initialize the particle with random positions and velocities.

Step 3: Calculate and compare the fitness value for each particle in the group of particles.

Step 4: Particle corresponding to the lowest fitness will be $p_{\text {best }}$. If the new fitness value for current input parameters is less than that obtained with $p_{\text {best }}$, then replace the input parameter values of $p_{\text {best }}$ with the present input parameter values .

Step 5: Check the velocity $v$ of each particle according to the following equations

$$
\begin{gathered}
v_{i}^{m+1}>v_{\max }, \text { then } v_{i}^{m+1}=v_{\max }, \\
v_{i}^{m+1}>v_{\min }, \text { then } v_{i}^{m+1}=v_{\min } .
\end{gathered}
$$

Step 6: Compare the fitness values of $p_{\text {best }}$ of all particles to determine the best particle and store the coordinates of the best particle as $g_{\text {best }}$.

Step 7: Modify the velocity of each particle according to the equation.

Step 8: Modify the position of each particle according to equation.

Step 9: If the number of iterations reaches the maximum, then go to Step 10. Otherwise, go to Step 3.

Step 10: The particle that creates the newest $g_{\text {best }}$ is the optimal solution of the problem

Step 11: Stop after a sufficiently good fitness value or a maximum number of iterations.

Table 2PSO Parameters

\begin{tabular}{|l|c|}
\hline \multicolumn{1}{|c|}{ Parameter } & Value \\
\hline No. of particles & 30 \\
\hline No. of iterations & 250 \\
\hline C1 & 1 \\
\hline C2 & 3 \\
\hline Initial inertia weight & 0,9 \\
\hline Final inertia weight & 0,8 \\
\hline
\end{tabular}

\section{Results and Discussions}

In order to validate the proposed controller, the simulations are carried out on multi-machine power system using MATLAB R2012a.

\subsection{Test system}

The test system used in this paper is 2 machine 3 bus system. It consists of a hydraulic generation plant (M1) having capacity of $1000 \mathrm{MW}$, which is connected to a load via a long $700 \mathrm{~km}$ transmission line. The load is designed as a $5000 \mathrm{MW}$ resistive load. The load is also fed by a local generation of $5000 \mathrm{MW}$ (M2). The system has been initialized in such a way that the transmission line carries $950 \mathrm{MW}$ which is nearer to its surge impedance loading of $977 \mathrm{MW}$. To maintain the stability of system after faults, compensation is provided at its midpoint by means of a FACTS device. The single line diagram of the proposed system is given in Fig. 7. Tab. 3 shows the specifications of the test system.

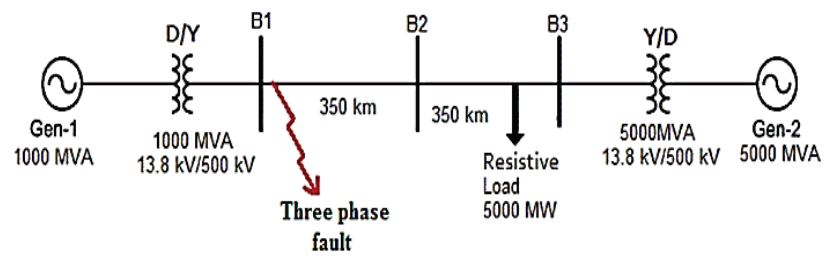

Figure 7 Single line diagram of test system

Table 3 Specifications of test system

\begin{tabular}{|l|c|}
\hline \multicolumn{1}{|c|}{ System parameters } & Rating \\
\hline Load centre & $5000 \mathrm{MW}$, Resistive load \\
\hline Power plant 1 (M1) & $1000 \mathrm{MW}$ \\
\hline Power plant 2 (M2) & $5000 \mathrm{MW}$ \\
\hline Initial power flow & $950 \mathrm{MW}$ \\
\hline Surge Impedance Loading (SIL) & $977 \mathrm{MW}$ \\
\hline Power rating of SVC & $200 \mathrm{MVAR}$ \\
\hline
\end{tabular}

\subsection{Simulation results}

Three phase fault is created at $t=3 \mathrm{~s}$ and circuit breaker is made to open at $t=3,1 \mathrm{~s}$ to clear that fault. The simulations are carried out on test system using 3 different controllers with PSS and SVC. They are

a) Conventional controller with PSS (Lead lag controller with manual tuning) and SVC (PI controller with manual tuning)

b) Fuzzy Logic Controller (FLC) with both PSS and SVC

c) PSO tuned controller with both PSS and SVC

The parameters like rotor angle deviation and transmission line active power are measured and the simulation results with each of the 3 controllers are presented from Fig. 8 to Fig. 10.

The parameters of SVC and PSS controller obtained by PSO are given in Tab. 4 and Tab. 5 respectively.

Table 4 Parameters of SVC tuned by PSO

\begin{tabular}{|c|c|c|}
\hline Parameter & $K_{\mathrm{p}}$ & $K_{\mathrm{i}}$ \\
\hline Value & 0,0355 & 298,1270 \\
\hline
\end{tabular}

Table 5 Parameters of PSS tuned by PSO

\begin{tabular}{|c|c|c|c|c|}
\hline Parameter & Gain & $T_{\mathrm{W}}$ & $T_{1}$ & $T_{2}$ \\
\hline Value & 2,9671 & 0,7830 & 0,0637 & 0,5015 \\
\hline
\end{tabular}

The comparison of simulation results with Conventional PI controller, FLC and PSO tuned controller is shown in Tab. 6 .

From Tab. 6 it is inferred that both the rotor angle deviation and line active power are less oscillated and stabilized faster with reduced peak value, after subjected to a three phase fault with the presence of PSO tuned PSS and SVC. The performance of PSO tuned PSS and SVC is better when compared with other controllers like conventional PI controller and FLC tuned PSS and SVC. 


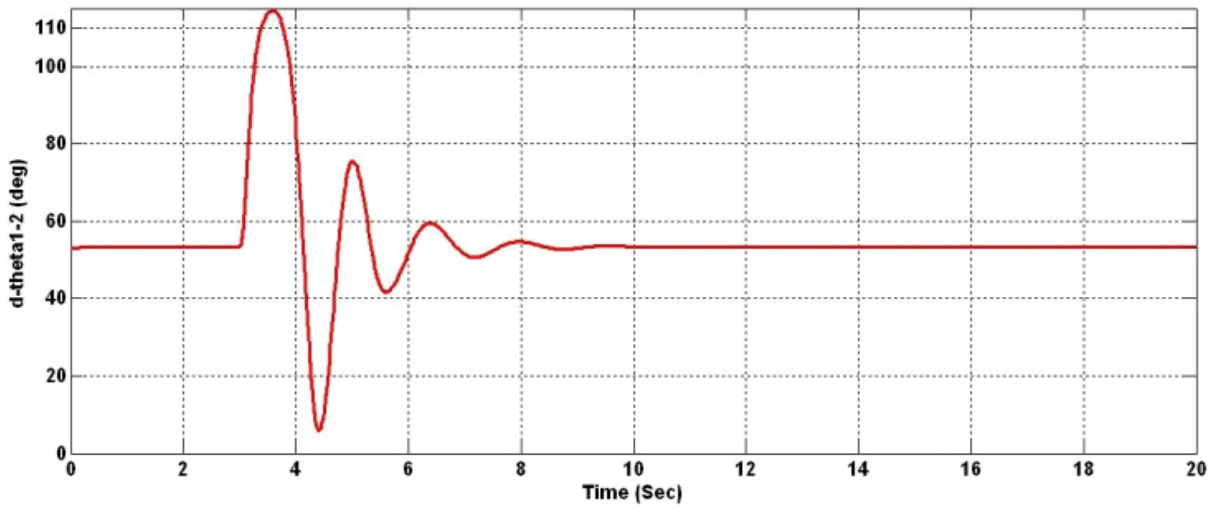

Figure 8 Rotor angle deviation with conventional PSS and SVC

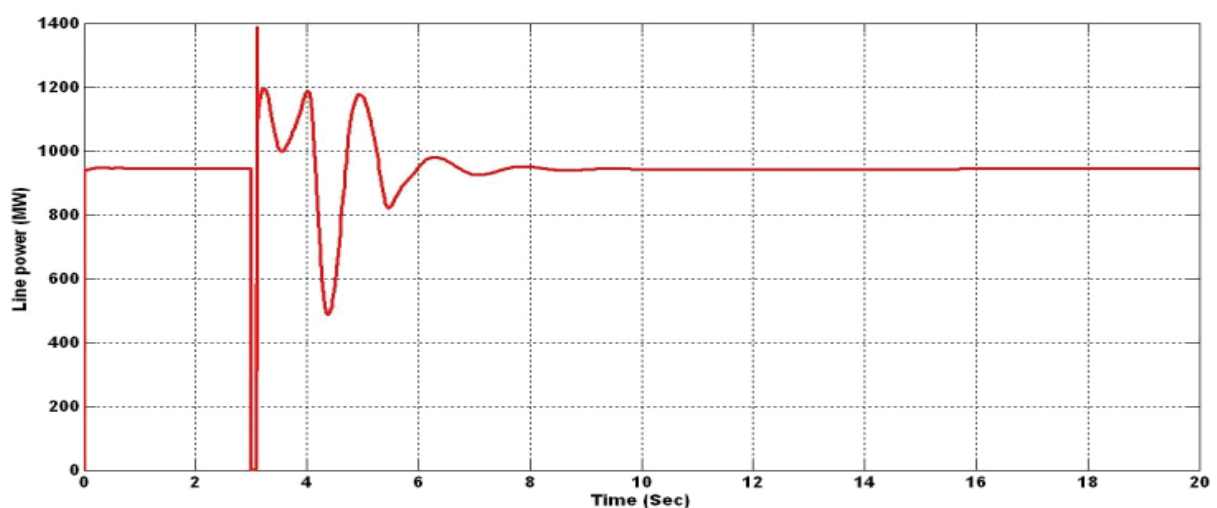

Figure 9 Transmission line active power with conventional PSS and SVC

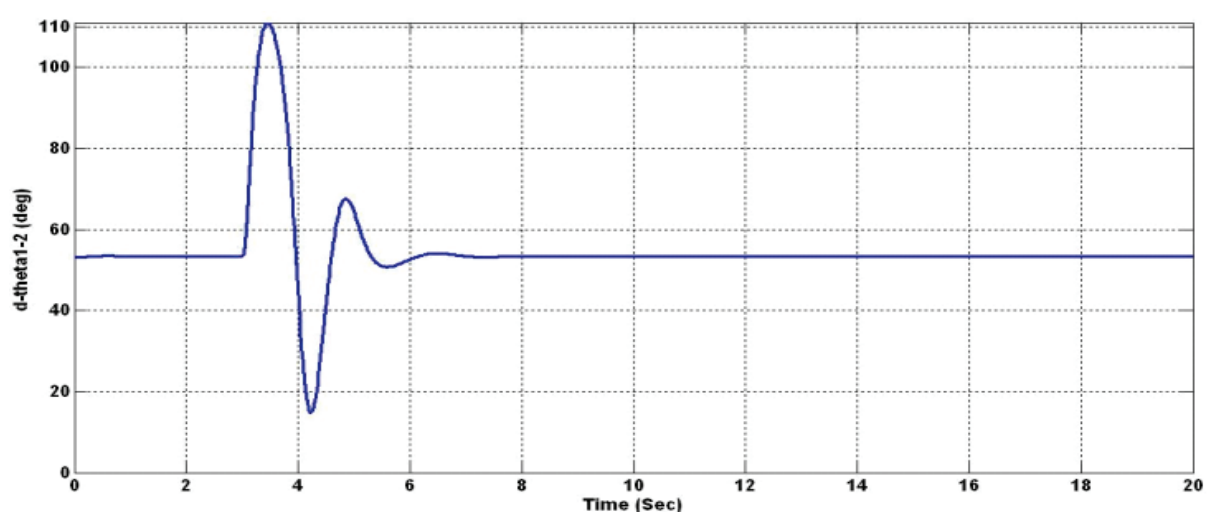

Figure 10 Rotor angle deviation with FLC based PSS and SVC

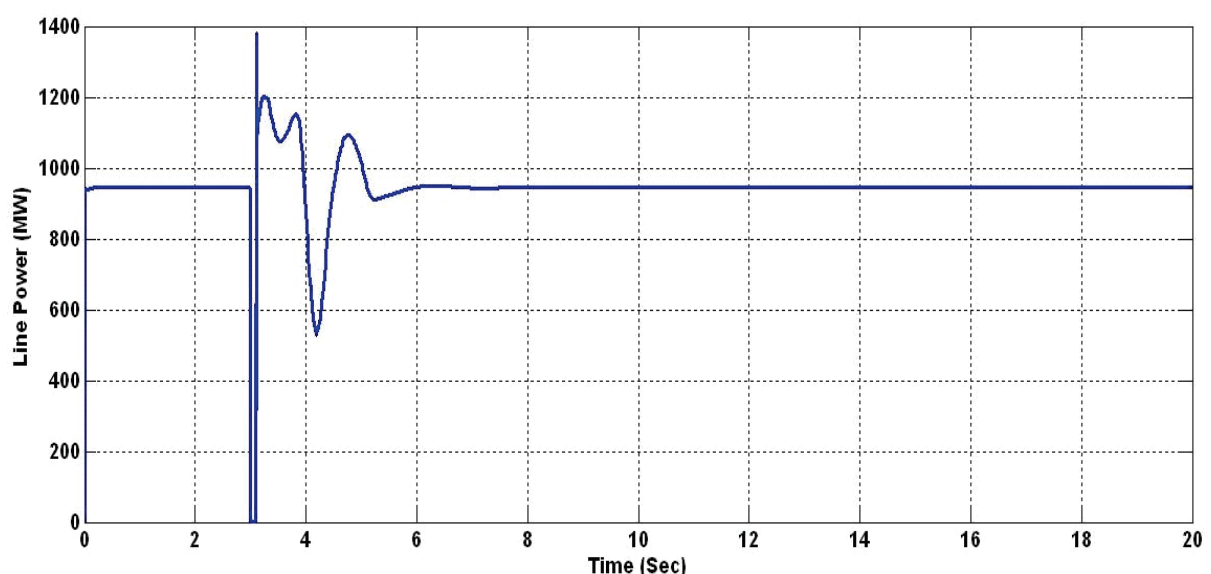

Figure 11 Transmission line active power with FLC based PSS and SVC 


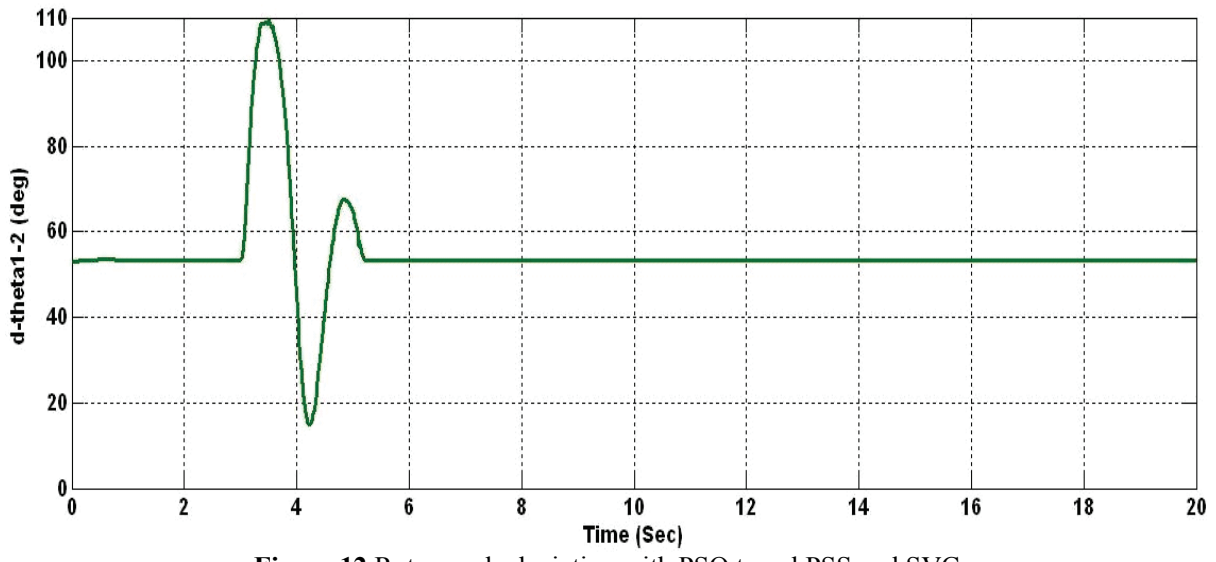

Figure 12 Rotor angle deviation with PSO tuned PSS and SVC

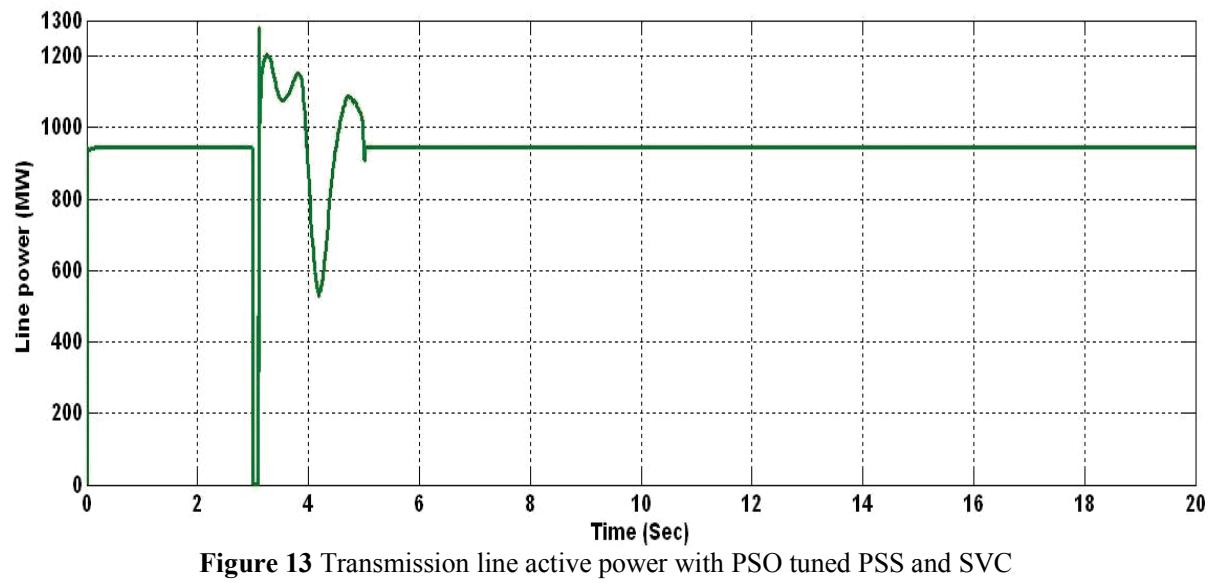

Table 6 Comparison of results with Conventional PI controller, FLC tuned and PSO tuned controller

\begin{tabular}{|l|c|c|c|c|}
\hline \multirow{3}{*}{ Parameter } & \multicolumn{2}{|c|}{ d-theta1-2 } & \multicolumn{2}{c|}{ Line power } \\
\cline { 2 - 5 } & $\begin{array}{c}\text { Peak } \\
\left(^{\circ}\right)\end{array}$ & $\begin{array}{c}\text { Settling time } \\
(\mathrm{s})\end{array}$ & $\begin{array}{c}\text { Peak } \\
(\mathrm{MW})\end{array}$ & $\begin{array}{c}\text { Settling time } \\
(\mathrm{s})\end{array}$ \\
\hline PI & 114 & 10,0 & 1400 & 9,0 \\
\hline FLC & 110 & 8,0 & 1380 & 7,0 \\
\hline PSO & 110 & 5,0 & 1300 & 5,0 \\
\hline
\end{tabular}

\section{Conclusion}

In this paper, a new method for coordinated control of parameters of PSS and SVC in power system is presented. For this purpose, the design procedure is converted to an optimization problem. In order to solve this optimization problem in a wide search region with a high convergence speed, PSO was used. For evaluation of the proposed coordinated algorithm, its performance is compared with conventional and Fuzzy based methods. Simulation and analytical results for multi-machine power system confirm the effectiveness and the robustness of the proposed design technique to enhance the dynamic characteristics of the power system. Analysis of results reveals that PSO is much better than Fuzzy in enhancing the power system stability.

\section{References}

[1] Abido, M. A.; Abdel-Magid, Y. L. Robust design of multimachine power system stabilizers using Tabu search algorithm. // IEE Proceedings Gener., Transmission. Distrib. 147, 6(2000), pp. 387-394. DOI: 10.1049/ipgtd:20000717
[2] Abido, M. A.; Abdel-Magid, Y. L. Analysis and Design of Power System Stabilizers and FACTS Based Stabilizers Using GA. // Proceedings of PSCC-2002, Session 14 Paper 3, Spain, June 24-28, 2002.

[3] Blasina, M.; Komen, V.; Cucic, R. Voltage control and Compensation of Reactive Power by SVC devices. // Eng. Rev. 30, 2(2010), pp. 47-58.

[4] Komen, V.; Blasina, M.; Cucic, R. Research on the Power Grid operation improvement by Static Var Compensators. // Tehnicki vjesnik-Technical Gazette. 19, 1(2012), pp. 57-64.

[5] Ertay, M. M.; Zengin, A. Analysis of the discontinuous PWM controlled D-STATCOM for Reactive Power Compensation Applications. // Tehnicki vjesnik-Technical Gazette. 21, 4(2014), pp. 825-833.

[6] Lei, X.; Lerch, E. N.; Povh, D. Optimization and coordination of damping controls for improving system dynamic performance. // IEEE Trans. Power Systems. 16, (2001), pp. 473-480. DOI: 10.1109/59.932284

[7] Pourbeik, P.; Gibbard, M. J. Simultaneous coordination of Power System Stabilizers and FACTS device stabilizers in a multi machine power system for enhancing dynamic performance. // IEEE Trans. Power Systems. 13, 2(1998), pp. 473-479. DOI: 10.1109/59.667371

[8] Sanchez-Gasca, J. J.; Chow, J. H. Power system reduction to simplify the design of damping controllers for inter-area oscillations. // IEEE Trans. Power Systems. 11, 3(1996), pp. 1342-1349. DOI: 10.1109/59.535675

[9] Eslami, M.; Shareef, H.; Mohamed, A.; Ghoshal, S. P. Tuning of power system stabilizers using particle swarm optimization with passive congregation. // International Journal of the Physical Sciences. 5, (2010), pp. 2574-2589.

[10] Mathur, M.; Varma, R. K. Thyristor-Based Facts Controllers for Electrical Transmission Systems. // A John Wiley \& Sons, Inc. Publication, 2002, pp 93-138. 
[11] Mithulananthan, N.; Canizares, C. A.; Reeve, J.; Rogers, G. J. Comparison of PSS, SVC and STATCOM Controllers for Damping Power System Oscillations. // IEEE Transactions on Power Systems. 18, 2(2003), pp. 786-792. DOI: 10.1109/TPWRS.2003.811181

[12] Hague, M. H. Improvement of first stability limit by utilizing full benefit of shunt FACTS devices. // IEEE Transactions on Power Systems. 19, 4(2004), pp. 18941902. DOI: 10.1109/TPWRS.2004.836243

[13] Larsen, E. V.; Swann, D. A. Applying Power System Stabilizers Part II: Performance Objectives and Tuning Concepts. // IEEE transactions on Power Apparatus and Systems. PAS-100, 6(1981), pp. 3025-3033. DOI: 10.1109/TPAS.1981.316410

[14] Arzeha, N. A.; Mustafa, M. W.; Idris, R. M. Fuzzy based Static VAR Compensator Controller for Damping Power System Disturbances. // IEEE International Power Engineering and Optimization Conference (PEOCO2012), pp. 538-542, Melaka, Malaysia: 6-7 June 2012. DOl: 10.1109/PEOCO.2012.6230924

[15] Khooban, M. H.; Maryam Abadi, D. N.; Alfi, A.; Siahi, M. Optimal Type-2 Fuzzy controller for HVAC Systems. // Automatika. 55, 1(2014), pp. 69-78. DOI: 10.7305/automatika.2014.01.219

[16] Lo Laiq Khan, K. L. Fuzzy Logic Based SVC for Power System Transient Stability Enhancement. // International Conference on Electric Utility Deregulation and Restructuring and Power Technologies 2000, IEEE, pp. 453-458.

[17] Karuppiah, N.; Malathi, V.; Selvalakshmi, G. Transient Stability Enhancement Using Fuzzy Controlled SVC and STATCOM. // International Journal of Innovative Research in Science, Engineering and Technology. 3, 3(2014).

[18] Aliakbar Golkar, M.; Zarringhalami, M. Coordinated Design of PSS and STATCOM Parameters for Power System Stability Improvement Using Genetic Algorithm. // Iranian J. of Elect. and Computer Engg. 8, (2009), pp. 8088.

[19] Shi, Yu-hui; Eberhart, Russell C. Empirical study of particle swarm optimization. // Proc. IEEE Int. Congr. Evolutionary Computation. 3, (1999), pp. 101-106.

[20] Clerc, M.; Kennedy, J. The particle swarm - explosion, stability, and convergence in a multidimensional complex space. // IEEE Trans. Evolutionary Computation. 6, (2002), pp. 58-73. DOI: $10.1109 / 4235.985692$

[21] Ratnaweera, A.; Halgamuge, S. K.; Watson, H. C. Selforganizing hierarchical particle swarm optimizer with timevarying acceleration coefficients. // IEEE Trans. Evol. Comput. 8, 3(2004), pp. 240-255. DOI: 10.1109/TEVC.2004.826071

\title{
Authors' addresses
}

\author{
Natarajan Karuppiah, Assistant Professor \\ Latha Mathavan Engineering College, \\ Latha Mathavan Nagar, \\ Kidaripatti Post, Alagarkovil, \\ Madurai - 625 301, Tamilnadu, India \\ E-mail: natarajankaruppiah@gmail.com \\ Veluchamy Malathi, Professor \\ Anna University Regional Office Madurai \\ 16, Sidco Estate, \\ Madurai - 625 007, Tamil Nadu, India \\ E-mail: vmeee@autmdu.ac.in
}

